\title{
Before empowerment: residents' memories of the role of the housemother in diaconal residential care settings in Germany 1945-1995
}

D. HÄNDLER-SCHUSTER ${ }^{1}$ PhD MScN MS ( nurse edu) RN, M. SCHULZ ${ }^{2}$ PhD MSCN RN \& J. BEHRENS ${ }^{3}$ phD habil

${ }^{1}$ Lecturer, School of Health Professions, Institute of Nursing, ZUAS Zurich University of Applied Sciences, Zurich Canton, Switzerland, '2Professor of Nursing (Mental Health), Diaconical University of Applied Sciences (FHdD), Bielefeld, Nordrhein-Westfalen, ${ }^{3}$ Professor and Head of the School (Institute) of Health and Nursing Science, Board of the German and Austrian Conference of the Deans of Nursing Science Faculties and President of the Middle and South German Nursing Science Research, Medical Faculty Halle-Wittenberg, Halle (Saale), Sachsen-Anhalt, Germany

Keywords: community care, history of mental health nursing, institutional dynamics, nursing role, power

Correspondence:

D. Händler-Schuster

School of Health Professions, Institute of Nursing, ZUAS Zurich University of Applied Sciences, Turbinenstrasse 71, P.O. Box

CH-8401 Winterthur

Switzerland

E-mail:

daniela.haendler-schuster@zhaw.ch

Accepted for publication: 27 May 2012

doi: 10.1111/j.1365-2850.2012.01946.x

\section{Accessible summary}

- In German institutions for people with mental illness, some woman lived and worked as 'housemothers'. In the 20th century, they played a very important role. This paper is based on interviews with people who lived in these institutions and looks at their experiences of a place where carers and people with mental illness lived together.

- Housemothers often spent decades living and working in the institutions. There are three main phases to their development: (1) 'Setting out as bride: borrowed power and domination'; (2) 'Realizing one's potential as a housemother: applied power and domination'; and (3) 'Leaving the housemother function: lost power and domination'.

- The findings show that the housemothers often felt that they did not get enough recognition for what they did from the deacons. Deacons in Germany are ministers in the Protestant Church who also have special training in social care. Housemothers did not just do housework; they were also caregivers who played a decisive role in resource-oriented care. The concepts of power and domination are very important here.

- The historical concept of houseparents helps us understand the current discussion about new forms of residential care homes and psychiatric care.

\section{Abstract}

In the 20th century, houseparent families represented a significant resource in the long-term care of people with mental illnesses and physical disabilities in diaconical care settings in Germany. In theory, such families could therefore be understood as a type of institutional family: groups which occasionally use familial patterns of reciprocity but are not themselves families. As little empirical material on life in institutional families existed, a qualitative study was undertaken to explore the experiences of contemporary witnesses, particularly those who had experienced the duties and responsibilities of housemothers in the second half of the 20th century. This paper has combined the experiences of residents $(n=8)$ and biological children of houseparents $(n=5)$ from a qualitative study $(n=42)$. The qualitative study took a grounded theory approach, with the phenomena of power and domination forming the central category. The findings show that life in houseparent families of the time was shaped by rules 
which the family members had to obey. This study explores a highly controversial area which is of great relevance for current mental health nursing practice: the power relations in diaconal families. This demonstrates the importance of integrating autonomy and empowerment into everyday communal life and contributes to professional nursing practice.

\section{Introduction}

This study explores the experiences of people living and working in institutional, family-like care settings in Germany run by the Diaconate, the social welfare organization of the Protestant church. Institutional families in such settings, referred to as diaconal, were still common in the 20th century in Germany. Nursing history shows that these houseparent families featured many of the characteristics of typical families, without being an actual family. Housemothers worked at the side of the housefathers to nurse and care for people who no longer had any other home. The houseparents had a variety of responsibilities, among them caring for people who were in need of psychosocial support or had psychiatric illnesses. However, what is known about these institutional families as a form of care provision is now in danger of being forgotten. Furthermore, the important contribution to care that the housemother made to this form of care has also been widely overlooked in the literature currently available. These two reasons underline the importance of research in the area.

The current debate surrounding 'new' forms of residential care means that references to the historical diaconal families can once again be found in the literature, but these do not take the strengths and weaknesses of the former system into account (Flückiger \& Widmer-Huber 2006, M. Faensen, 2007, unpubl. manu.). The term 'housemother' can also be found (e.g. in the context of the 'cantous' model of care) without any reference to the history of the concept in institutional family settings. An analysis of the available literature, focusing on primary sources and archive material (Händler-Schuster 2012, D. Händler-Schuster et al., 2012, unpubl. manu.), shows that there is a particular lack of empirical material on the former members of the institutional families. Additionally, none of the sources give a detailed account of the experiences of former housemothers in terms of their nursing practice, nor do they offer any information about how women experienced the process of becoming a housemother.

In order to safeguard the valuable knowledge about institutional families in the diaconate (Protestant social care ministry) from the perspective of those who experienced it first-hand, a research project was started with a particular focus on the role of the housemother. This paper presents the role of the housemother from the perspective of residents and biological children who lived as members of the institutional families. The research question was 'How did residents and biological children of former houseparents experience life in the institutional families of the diaconate in retrospect?' The findings will contribute towards improving knowledge about the function of the housemother in institutional families in diaconal care settings in the second half of the 20th century. They will also contribute towards a better understanding of the development of psychiatric care in Germany. By creating a home for people with a variety of mental disabilities in which the residents felt at home, housemothers in diaconal institutional families played an important role in the provision of psychiatric care, particularly in the second half of the 20th century.

In addition, the perspectives of residents and biological children could help improve the understanding of the history behind the development of 'modern' family-like settings. On the one hand, this helps to complete the picture of institutional families of the past. On the other hand, the findings represent an important resource for discussions concerning new forms of living and community housing models, in view of the ageing population.

This paper is pioneering. For the first time, the former residents of houseparent families were asked about their memories as part of an empirical study. The aim was to use a different perspective to gain a fuller understanding of the role of the housemother. This paper is currently the only publication which focuses on the memories of both former residents and the biological children of those houseparent families which provided a form of mental health nursing.

As the paper discusses a form of care which has received little attention in nursing history, the first part of the paper will use the example of one diaconal setting to offer an account of how the houseparent families as a form of nursing care came into being. The subsequent section on the methodological process will discuss how it was possible to gain access to people with first-hand experiences of the families and ask them about their memories. This section also outlines the methodological process behind the study. 
The findings show that life in houseparent families was characterized primarily by power and authority. This may account for the power that housemothers had in their position at the side of the housefathers, as well as explaining why such a role was able to exist for over a hundred years (Händler-Schuster 2011, Händler-Schuster et al. 2011, 2012, D. Händler-Schuster et al., 2012, unpubl. manu.).

\section{The history of diaconal institutional families in Germany}

The origins of diaconal institutional families can be traced back to the 17th century. Traces of them can be found in the history of institutional care (Obst 2002, Häusler 2007, Sattler 2007). Houseparents were typical in several diaconal settings in Germany. The literature shows that the first houseparents were active from 1894 to 1919, that is, for 25 years, at the von d. Bodelschwinghschen Stiftungen Bethel, the biggest diaconal organization in Europe (Frick 2002).

Generally speaking, houseparents consisted of a deacon and his wife or a deaconess and a minister (see Benad 2008, Neumann 2010). The deacon and his wife lived together in one house with their own family, that is, with their biological children, and with the people who needed their care. The 'external' family members included homeless people, alcoholics, elderly and frail people but also those with psychiatric illnesses and epilepsy. Together with the houseparents, they formed a 'family'.

Historical documents suggest that houseparent families were initially intended to form small living units (6-12 people) (J. Busch, 1992, unpubl. manu.). However, the political situation (war, shortages and poverty) meant that the small units which had been planned turned into larger homes in which the houseparents often lived with over a hundred people in need of care. Up until the 1970s, houseparents segregated the sexes in the care homes, reflecting their duty to ensure the sexual abstinence of the unmarried deaconesses, kitchen assistants and deacons in training (Meyer zu Bargholz et al. 1975).

The housemothers' duties included providing nursing care for the 'sick' and 'needy', as well as running the household and organizing the residential aspects of the home. It was their duty to create a 'motherly' atmosphere in the home (Tegtmeyer 1948). The first houseparents at Bethel worked there for 25 years, from 1894 to 1919. Unpublished documents reveal that in 1959 there were still 134 houseparents at Bethel, each couple consisting of a deacon and his wife (R. Falkenroth, 1995, unpubl. manu.). Numbers started to decline in the 1960s and in 1995 only 20 houseparents remained at Bethel.
It can be argued that developments in professional nursing practice, particularly in the second half of the 20th century, influenced the reform movements which sought to give more autonomy and empowerment to people living and receiving care in institutional families (H. Rosemann, 1966, unpubl. manu., Steinbrück 2001, Randzio 2008). The houseparents were the first point of call for residents, relatives and medical staff and provided important links between the groups.

Historically, houseparents represented hope to the many people in need of their care (Neumann 2010). This can be seen for example in Section 2 of the undated instructions for housefathers, which state that it was the duty of houseparents to provide a replacement for patients' own homes, in the sense of the family members (P. Brinkmeier, 1994, unpubl. manu.). It is important to emphasize the use of 'home' here. In contrast to a hospital, a family home is a place where the members of that family do things for each other; clinical managers in a hospital do not use patients to replace auxiliary healthcare staff.

From a nursing history perspective, the diaconal institutional family belongs to a significant branch of nursing that has had a strong influence on inpatient nursing care. The culture of diaconal settings began to change in the 1960s (Benad 2008) and houseparents became less common. The reasons for this lie on the one hand in the professionalization of nursing, and on the other in the introduction of comprehensive social insurance. The changes were also influenced by the idea that greater personal freedom could be granted to deacons working in psychiatric health care (Randzio 2008). Furthermore, women's understanding of their role had also changed and fewer and fewer women were willing to work as housemothers in the relatively poor conditions of the homes. As part of the professionalization process, a new significance was also attached to the residents of the care homes. As a result, the work between professionals and their clients became to be seen as a process of interaction, in which case-based reasoning, or casuistry, became increasingly important (Oevermann 1997).

\section{Methodological approach}

In order to be able to describe the perspectives of former members of institutional families, a total of eight male residents and five biological children of former housemother were asked about their retrospective memories using oral history interviews (Heinz \& Behrens 1991, Hackmann 1999). An analysis of primary sources from archives also took place. The analysis followed a grounded theory approach, using line-by-line analysis 
(Corbin 2002). A combination of these two processes was used in an attempt to understand and interpret the participants' memories of the interactions, in order to deduce valuable insights from their stories which could be useful for nursing practice in the future. The present study can be distinguished from ethnomethodology in the sense that the focus was not on the meanings which individual members of houseparent families attached to their reality and everyday actions, but rather on the construction of meanings, as these emerged from the social interactions.

\section{Sampling}

Access to contemporary witnesses who could remember life in institutional families was hampered by headlines in the media reporting abuse and violence in former care institutes. The best access was provided by a diaconal community in Germany and as a result its members (approx. 1000) were informed about the study via a small community newsletter. Five biological daughters of former houseparents responded and agreed to be interviewed. Through contact with a former housefather and a former housemother, access was also gained to eight former male residents from Bethel who had spent several decades living in various diaconal institutional families and who also agreed to be interviewed in person.

All of the male residents, apart from one, now live in smaller residential groups and are supported in everyday living by carers. The other resident lives independently in a flat outside Bethel. The participants were contacted at random. As there are so few contemporary witnesses remaining, the residents and the biological daughters were not chosen according to any inclusion or exclusion criteria.

\section{Ethical guidelines}

Following consultation with the Ethics Commission of the Medical Faculty at Halle (Saale) it was agreed that as long as data protection requirements and principles of ethical research were observed, it was not necessary for the commission to hold a vote on this study with residents who were capable of giving informed consent. All participants were informed about the aims of the research orally and also in writing. Participants' autonomy was respected by asking them to sign a consent form giving permission for their anonymized memories to be published by the author. The age of the residents and information on the settings they had lived in was deliberately not mentioned for data protection reasons.

\section{Data collection}

Taking the findings of an earlier study by J. Behrens (2008, unpubl. manu.) as a starting point, it was decided that interviews should focus on the following themes: division of labour, teamwork, the role of the housemother and sacrifice. Questions for the interviews with residents were deliberately kept simple and open, for example: 'What did the housemother do?' or 'Where did she spend her time?', 'What was it like when there were still housemothers?' 'What was it like being the biological child of a houseparent family?' Targeted follow-up questions in the interview were used with the aim of making the respondents' comments as clear and comprehensible as possible (Lamnek 2005).

\section{Data analysis}

The first author carried out and fully transcribed all the interviews, which were recorded digitally. A co-author was present at three of the interviews. The data were analysed using the MAXQDA program, a software tool for computer-aided qualitative data and text analysis. The data were analysed in a multi-step coding process involving open, axial and selective coding (Strauss \& Corbin 1996). All the transcripts were analysed three times and categorized accordingly, creating a more refined categorization each time. Following analysis of the interviews, each of the co-authors gave written and oral feedback to the first author, commenting, confirming or questioning the categories.

\section{Procedure}

The study as a whole followed the general quality criteria of hermeneutic interpretive research (Strauss \& Corbin 1996). Reflecting this, its aim was to reflect the real lives of housemothers and former members of houseparent families by generating a theory. Through the process of theory generation, the wider study aimed at generalizability by comparing various settings and contexts in which housemothers worked. A further aim was to represent the research process and the presentings of findings in various publications from the wider study in such a way as to make them understandable and clear to both participants and professionals.

\section{Research findings}

The present paper concentrates exclusively on the experiences of residents and biological children of former houseparent couples in terms of the role of the housemother. The 
results are organized around the two central phenomena of power and domination. Two main influencing factors were defined: 'Living in the Institute's House' and 'Personality and Competencies' (Händler-Schuster 2011, HändlerSchuster et al. 2011, 2012, D. Händler-Schuster et al., 2012, unpubl. manu.)

\section{Representing the findings}

The findings of the interviews are presented here in two parts. The first section presents the findings from the interviews with the former residents and the second from the interviews with the biological children.

\section{The role of the housemother from the perspective of Bethel residents}

The analysis of the eight interviews with the male residents led to four categories being defined: (1) 'Recognition through work and structure'; (2) 'At the mercy of the houseparents: eating as an arena of dependence' (3)'Being good and obeying'; and (4) 'Longing for affection'. The categories are not presented in chronological order.

Category 1: 'Recognition through work and structure' Work was a central part of all the residents' daily lives. Working for the houseparents meant that they would receive something in exchange. The housemothers recalled the rewards they used to give. Mrs U. gave small tokens to residents who had tried hard to do something despite their disabilities. She had to justify these extra costs in the bookkeeping when costs arose which she could not account for as part of normal outgoings.

Mrs W. also remembered giving rewards or small payments to residents who helped in the kitchen: 'A lot of them liked it, they had a bit of contact with the kitchen, got an extra slice of bread and butter, not that they went hungry, but it meant they got a special treat or something'.

The residents who were interviewed did not directly remember being giving rewards by the housemothers. However, they did recall rewards from housefathers. In general, it can be said that these small rewards were not gifts, as they were given in return for work which would otherwise have been renumerated with a salary or wage. The men, women and children worked in the institutional family in exchange for food and lodging as well as small rewards. Typically, the housemother was solely responsible for deciding when to distribute these rewards - just like in the family.

While the housefathers generally had direct responsibility for instructing the residents, supervising and accompanying them, the housemothers were responsible for creating a familial atmosphere and bringing their motherly skills to bear on the residential environment. The housemother was usually in charge of running the kitchen, the sewing room and the laundry facilities, as well as supplying food and instructing the female members of staff (Tegtmeyer 1948).

The literature shows that the housemother, her husband and their biological children were entitled to a private family life, but she was also to be available day and night to provide motherly devotion to one or two hundred other people (Tegtmeyer 1948).

Category 2: 'At the mercy of the houseparents: eating as an arena of dependence'

Memories of mealtimes were significant for all the residents. This was revealed by the fact that talking about this topic triggered emotions. $\mathrm{Mr} \mathrm{M}$. and $\mathrm{Mr} \mathrm{W}$. remembered independently of each other that while the housemother sometimes took the residents' wishes into account in the kitchen, this was not always the case and they were dependent on her good disposition for this. On the other hand, Mr G. remembered arguments and strict controls, which he described very emotionally: 'She always made me - we had to eat bread soup. That doesn't agree with me [pulls a face - disgust]'.

For some residents, working in the kitchen was clearly an advantage as this meant they could help in the kitchen and were consequently able to eat not only the food that had been allocated to them, but also the leftovers from the houseparents and other staff: 'It was all slops... We were lucky in the kitchen - leftovers would come back from upstairs, from the staff, and we'd stuff our faces' (Mr H.).

These findings show that different groups in the houses received different kinds of food, with the residents clearly receiving poorer quality food than the houseparents and staff. This made the residents dependent on the houseparents. They were at their mercy, as they had no say in the preparation or distribution of meals.

Category 3: 'Being good and obeying'

The importance of obedience in order to avoid punishment featured in various ways in the interviews. Residents remembered that the 'naughty ones' were sent away and did not come back, and that it was important to address the houseparents formally, as 'Housemother' and 'Housefather' and to greet them by shaking their hand. $\mathrm{Mr} \mathrm{H}$. remembered strict rules, such as those at bedtime:

'It was so hot, and we had to be in bed by 7 . We couldn't go to the lav - the loo - before 10.00, that was best of all. Sometimes you had a cold and you had to - it was always worst in the afternoons - put your head on the table ... it was quiet hour and that's what you had to do.' He only 
experienced greater freedom once the dormitories were converted into smaller bedrooms. The data suggest that once the houses became smaller, the housemother also had more time for the male residents, which improved her relationship to them.

\section{Category 4: 'Longing for affection'}

The majority of the participants memories show that affection and the desire for friendship represented something important in daily life:

Wednesday was visiting day and Sundays and if no-one came to see you, you just went into a corner and cried, that was normal. But you couldn't show it... (Mr H.)

It also became clear that the withholding of affection also played a central role. Mr G. remembered clearly that he had wanted affection from the houseparents but had not received it. One explanation for this could be that the housemother's primary responsibility was not to accompany and care for the 'family members', but to ensure the household ran smoothly.

\section{The housemother function from the perspective of biological daughters}

A total of five daughters agreed to talk about their memories. Analysis of the five interviews produced six categories:

(1) 'Helping to the best of your abilities - recognition of achievement'; (2) 'The housemother as a kind soul'; (3) 'Respect'; (4) 'Supporting each other'; (5) 'Obey the rules or be punished'; and (6) 'Sacrificing one's private life'. The categories are not presented in chronological order.

Category 1: 'Helping to the best of your abilities - recognition of achievement'

All the interviewees remembered that the housemother had clearly defined duties and responsibilities, predominately related to housekeeping. Three out of five women thought in retrospect that it was natural that they helped out in the household as children and supported the housemother. The findings show that all the interviewees described how the housemother and the housefather incorporated the residents' abilities into the daily routine: 'My father and mother paid a lot of attention to peoples' abilities and thought about what they could do or would do if you asked them or helped them. So I think that when the residents say, the parents weren't houseparents, they were our parents, that shows how much trust there was.' (Mrs V.)

It can be seen here that the residents who were ill and in need of care were not reduced to their status as patients, but seen as members of an institutional family who were engaged in work and caregiving activities and received recognition for their achievements.
Category 2: 'The housemother as a kind soul'

It seems clear that the role of the housemother was very important. All the respondents reported that the housemother served as a balance to the often stricter figure of the housefather and took the needs and wishes of the residents into account: 'They had this huge pan and they'd make potato pancakes for 80 men and if they knew that old Bolze likes Obstsuppe [a kind of dessert], then everyone knew that Bolze would get five bowls and everyone else just the three.' (Mrs K.)

\section{Category 3: 'Respect'}

Mrs G. described how the function of the houseparents in Bethel represented something special and could be compared with that of an authority figure. Even if there were disturbances in the houses, she recalled that her parents were secure in their position. Mrs E. said that it had not been easy for her mother: 'We always thought, I don't know how she puts up with it ... but on the other hand, they were doing all right for themselves and they could afford to buy things and for her that was the compensation.'

Mrs K. mentioned that her mother had often doubted herself as a housemother, which she herself found difficult to understand, as residents and staff had come to visit her mother until she died: 'She always said she couldn't delegate. But that wasn't true, she could delegate perfectly well, but the way she saw things was often influenced by her fear of failure, and that wasn't obvious to the outside world.'

\section{Category 4: 'Supporting each other'}

Mrs V. recalled that when residents were not well, her mother was there for them and offered them support and tea: 'Almost every mealtime, someone would have a big fit and six, eight people would immediately go up to him and carry him to bed and my mother would make tea and there were dormitories, 20, 26 people to a room, and I know my mother used to go in and take them a cup of tea.'

The 'people' mentioned here had epilepsy too, but assumed first-aid roles if they were not having a 'big fit' themselves. In other words, residents with severe chronic illnesses were also never seen as just patients, but always as recognized auxiliary caregivers. Mrs V. also recalled that the residents helped out in everyday life and that it was important for the functioning of the institutional family that their skills were incorporated:

We needed the fitter ones, the smarter ones, the mentally disadvantaged or the weaker ones, I remember all the there were mental, someone had a mental impairment, but it wasn't constant, it came in sort of bursts, and my father would speak to him and he got quite tough sometimes: 'Now, Siegfried, that's enough, go to bed'. Like 
that, there weren't any drugs back then, the people weren't sedated, they were sent to bed very energetically and when they'd slept for a few hours - they were all right again.

Category 5: 'Obey the rules, or be punished'

The children all reported that obedience was important in Bethel: 'We were never allowed to go outside before 3 PM, because that was the time of the crucifixion, and that's just how it was. After three, and when the sun was shining, it was particularly awful to have to stay inside.' (Mrs G.)

Mrs V. also recalled that she had had to practise making sacrifices as a child and had not been allowed to do everything she would have liked. Sanctions involving the residents were also a theme: 'If they didn't toe the line, they were put in the "cubbyhole", it was a small room, all stone, nothing but stone. And they just had to sit on the stone all day and at night they got a thin mattress.' (Mrs E.)

Category 6: 'Sacrificing one's private life'

All the children interviewed recalled a life with the residents which they associated with sacrifice. 'One of the houseparent couples, I used to be quite jealous of this, I used to think, I want that too, they had a private apartment with a bell. If you wanted to get into the room, you had to ring the bell. Where we were, the men could come right in to my parents' bedroom, they'd come in during the night, if someone had had a bad fit.' (Mrs V.)

The precursor to this study (J. Behrens, 2008, unpubl. manu.) also revealed the need for stronger boundaries between the biological family and the house family, and that the biological children were jealous of the residents that their parents were responsible for: 'I'm sure my mother would have liked to have had more of a family life and she worried terribly that we were essentially growing up with strangers.' (Mrs E.)

\section{Discussion}

These findings suggest that the culture in the houseparent families changed in favour of a freer and more autonomous way of life which permitted more self-determination and empowerment. The male residents' memories suggest that clear structures which the residents had to follow determined everyday life in the care institutes at Bethel. This confirms the findings of Nussbicker (2009).

It could be argued that the relationship between houseparents and residents was communicated discursively, particularly by using the sense of being a family (albeit an institutional one). An example of this is the rule that required residents to call the heads of their house 'housemother' and 'housefather'. The same use of familial norms for what was in reality only an institutional family can be seen in the use or rather misuse of the Fourth Commandment: 'Honour thy mother and thy father' was quoted by the directors of Bethel in order to demand obedience from the residents of the many care homes, particularly regarding religious observance (Benad \& Schmuhl 2006, p. 29, Benad 2008, p. 5).

Bethel's structures were designed to reflect literally the concept of hierarchy (lit. 'rule of a priest'). To achieve this, the familial norms were taken from the Bible and applied to the institutional family: residents had to respect the heads of their houses and understand that 'naughty' behaviour would have consequences, potentially even incarceration in the institutional family's own prison. It can also be assumed that a further consequence would have been transfer to another house (Nussbicker 2009), that is, that the houseparents would send their institutional 'children' and those under their protection 'away' to other houses. The high number of documents concerning transfers of residents also suggests that the care homes at Bethel were organized according to a hierarchy of 'severity of problem', confirming the findings of Rosemann (1966).

A further deduction that can be made from the reminiscences of the residents and the daughters of former houseparents is that the houseparents followed traditional gender roles which were presented to them as justified by the Bible: the woman was subordinate to the man. This may explain why so little was said about the function of the housemother in the interviews, despite this being the focus. Further findings from the study as a whole show that the women became increasingly emancipated in their professional lives and carried out a variety of care-related tasks (Händler-Schuster 2011). The findings of this study reveal that participants often recalled instances of strictness, as well as rules which had to be followed.

According to the German sociologist Popitz (1992), domination can be described as a form of institutionalized power. His 'forms of power' offer a useful way of interpreting housemothers' perceptions of their power. According to Popitz, a power becomes extended when it occurs in a fixed framework. As a result, it becomes organized and is therefore no longer necessarily attached to concrete situations. Popitz's forms of power can be transferred to the phases of the housemother role, which is why they are discussed here.

The table below relates Popitz's (1992) forms of power to this study (Table 1 ).

All four forms of power were strengthened through various factors, for example, through the close ties between the various houseparent families, but also through the language that was used and through the rules which applied to all the care homes. 
Table 1

The phases of the housemother role and the forms of power (Händler-Schuster et al. 2011)

\begin{tabular}{|l|l|l|}
\hline $\begin{array}{l}\text { The phases of the } \\
\text { housemother role }\end{array}$ & $\begin{array}{l}\text { Forms of power } \\
\text { (Popitz, 1992) }\end{array}$ & $\begin{array}{l}\text { Examples of how the basic forms of power } \\
\text { are manifested }\end{array}$ \\
\cline { 2 - 3 } $\begin{array}{l}\text { 'Setting out as a } \\
\text { bride'- borrowed } \\
\text { power and domination }\end{array}$ & Action power & $\begin{array}{l}\text { The ability to harm another person and control } \\
\text { them }\end{array}$ \\
\hline $\begin{array}{l}\text { Realising one's } \\
\text { potential as a } \\
\text { housemother- applied } \\
\text { power and domination }\end{array}$ & $\begin{array}{l}\text { Data-setting } \\
\text { power }\end{array}$ & $\begin{array}{l}\text { Technical ability to act, determined by } \\
\text { possession; division of labour, carrying out } \\
\text { changes }\end{array}$ \\
\hline $\begin{array}{l}\text { Leaving the } \\
\text { housemother role - } \\
\text { lost power and } \\
\text { domination }\end{array}$ & $\begin{array}{l}\text { Instrumental } \\
\text { power }\end{array}$ & $\begin{array}{l}\text { Creating fear and hope, for example through } \\
\text { rewards. Fear of rejection or attention. }\end{array}$ \\
\hline & $\begin{array}{l}\text { Authoritative } \\
\text { power }\end{array}$ & $\begin{array}{l}\text { Basis of authority, security and social orientation. } \\
\text { Creating an atmosphere, living in the house }\end{array}$ \\
\hline
\end{tabular}

It follows that residents had little say in their daily lives, which limited their freedom to make their own decisions. Following the theory of Popitz (1992), this represents an 'action power' and also an 'instrumental power'. 'Action power' describes the ability to harm someone or make decisions that affect them; 'instrumental power' on the other hand can use rewards and affection to create fear or hope (Händler-Schuster et al. 2011).

The actions of the houseparents were guided by instructions from the directors of Bethel, as well as by rules which had to be observed by everyone living in the house. A further aspect to this is that meals were to be taken communally with the houseparents in the dining hall, which was seen as unusual. The family members came together in the dining hall and this gave structure to their day. The use of an old familial ritual of eating and singing together (J. Behrens, 2008, unpubl. manu.) enabled the houseparents to pass on information to all the members of the houseparent family at the same time, but also to check that they were all present.

The kind of food the residents received in Bethel was decided by the directors. Holidays were special days in the sense that attending the parish church service was compulsory for all. Leisure time was also regulated: if the weather was good, residents were to go for walks; there was also provision for family evenings which had to feature games. Work was seen as a cure which would maintain spiritual equilibrium. It was seen as important for each individual in the house and as contributing to a harmonious coexistence.

Despite the many regulations from the directors of Bethel and the detailed house rules, there were no rules concerning the allocation of work itself. Just as in a family, the members of a house could allocate tasks according to both their personal preferences and abilities - as long as they had sufficient power to do so. The houseparents were thus more able to do this than the residents. Tasks were not allocated on an impersonal, role-based system, but personally.

The daughters of former houseparents confirmed the recollections of the residents to the extent that they also stated that work and the recognition of the residents as co-workers was an important element of daily life and that the houseparents felt responsible for everyone who lived in their house. They also confirmed that the housefathers were particularly strict towards the other residents of the house. This was described by one of the daughters, who remembered that her father had been strict with a resident so he would go to bed, which would prevent him from having a fit.

The literature shows that the development of medication was gradual at first and that for a long time, the only drug that could be used to treat the residents was 'kalibrom'. 'Kalibrom' was replaced by 'luminal' in 1910 and by the 1930s more modern anti-convulsion medication from the USA could also be used (Gramlich 1967).

It can be assumed that the houseparents often believed a strictly run house was necessary to maintain the order which made communal life possible. The study also found that precisely because of their nursing qualifications, housemothers were involved in professionalizing carerelated tasks (Händler-Schuster et al., 2011, HändlerSchuster et al. 2012, D. Händler-Schuster et al., 2012, unpubl. manu.). This reflects the trend which attached growing importance to competencies and qualifications and lessened the power of houseparents.

Weber (1980) defined domination as 'the probability that certain specific commands (or all commands) will be obeyed by a given group of persons'. Obedience or 'toeing the line' does not have to be voluntary; it can also result 
from fear (Roth 2010). The study findings show that both residents and the daughters of former houseparents obeyed the rules, although they may have been motivated in this both by fear as well as hope for recognition and affection. The belief in legitimacy created a strong foundation for the development of domination in the houseparent families. It can be argued that the traditional form of domination was legitimized by the regulations which structured communal life and were widespread throughout the institute, for example, the house rules (Roth 2010). The results suggest that the residents lacked autonomy and were not empowered.

The literature shows that in 1984, residents with epilepsy had no furniture or private space and were often sent to isolation cells, euphemistically known as 'the cubbyhole'. This backs up the biological daughters' descriptions. Entries in the isolations book show that residents were often put in isolation for disciplinary reasons (Nussbicker 2009). However, being put in isolation was also the only opportunity for residents to be alone.

The results demonstrate that the housemother often functioned as the kind soul of the house, cooking meals for residents or bringing them tea. She would also often appeal to her husband, the deacon, on behalf of wrongdoers and others in need - just like Mary, mother of Jesus and God.

The interviews with daughters of former houseparents suggest that the divided attention of the housemothers may have created feelings of neglect among the biological children. This reflects the statements of some former housemothers, who recalled that it was not always easy to combine family and work and that the family's private life often suffered.

Against the backdrop of wider change, the conditions in the houses also changed rapidly from the 1970s, from complete external control (heteronomy) to externally controlled autonomy (Steinbrück 2001, Randzio 2008, Neumann 2010).

Further findings from the study show that houseparents represented an enrichment for those living in the house, as their constant presence created a sense of security. The interviews with residents and biological daughters of former houseparents reflect a social change, in which the culture of nursing care began to allow a slightly more autonomous way of life than the strictly imposed quasi-familial interpretation of the Fourth Commandment (Behrens 2005).

The houseparents were the primary attachment figures and created security and a sense of orientation through their presence, although this was bound by rules which limited the autonomy of those living in diaconal families.

A weakness of this study is that some of the male residents interviewed had severely impaired communicative abilities. The role of the housemother was often only mentioned after repeated questioning and some of the residents remembered very little about the topic. Furthermore, only the experiences of male residents and biological daughters of former houseparents were investigated. The perspectives of female residents and biological sons of former houseparents could not be explicitly explored.

\section{Conclusion}

The finding of the analysis of the institutional families in the diaconate that is most significant for the future is the fact that among all the pseudofamilial abuses in the institutions at Bethel the positions of patient or client on the one hand and therapist, nurse or social worker on the other were never clearly differentiated. Those in need of care were never primarily patients or clients in the diaconal institutes, but rather members of a working community who were recognized for their contributions (J. Behrens, 2008 , unpubl. manu.). In the context of the misuse of appeals by the institutional families at Bethel to forms of familial reciprocity, this insight offers an opportunity to reflect on the treatment of those in need today.

Follow-up studies could explore the theme of sexuality. The houseparents had the monopoly on legitimate sexual intercourse until the 1970s (Meyer zu Bargholz et al. 1975). Further research is needed into illegitimate sexual intercourse, but also the more general satisfaction of the need for intimacy and affection. A further theme that could only be touched on here is that of homesickness and missing one's own family. Apart from the houseparents, residents had biological parents and siblings, who were idealized in moments of homesickness. Further research here could examine the contribution that nursing care can make towards accepting and acknowledging feelings of homesickness.

\section{References}

Behrens J. (2005) Soziologie der Pflege und Soziologie der Pflege als Profession: die Unterscheidung von interner und externer Evidence. In:
Soziologie der Pflege (eds Schroeter, K.R. \& Rosenthal, T.), pp. 51-59. Grundlagen, Wissensbestände und Perspektiven, Weinheim, München, Juventa.

Benad M. (2008) Auf dem Weg zur religiösen Selbstverantwortung. Zum Wandel der religiösen
Alltagskultur in diakonischen Einrichtungen nach 1945. Journal of Religious Culture 101, 4-9.

Benad M. \& Schmuhl H.-W. (2006) BethelEckartsheim. Von der Gründung der ersten deutschen Arbeiterkolonie bis zur Auflösung 
als Teilanstalt (1882-2001). Kohlhammer, Stuttgart.

Corbin J.M. (2002) Forcing vs. Emergent: line by line analysis. Paper Presented in Halle, Germany, September 27. In: Hallesche Beiträge $z u$ den Gesundheits- und Pflegewissenschaft. 3 (ed Behrens, J.). Jahrgang, Halle. Available at: http://www.medizin.uni-halle.de/fileadmin/

Bereichsordner/Institute/

GesundheitsPflegewissenschaften/

Hallesche_Beitr\%A4ge_und_EBN/Halle-

PfleGe-03-01.pdf. (accessed 12 December 2009).

Flückiger K. \& Widmer-Huber T. (2006) Neue Wohnprojekte braucht das Land. Wohnmodelle und Gemeinschaften mit diakonischem, pädagogischem, therapeutischem Auftrag. Ein Handbuch für amtierende und künftige Hauseltern und LeiterInnen. 4. Aufl. Schriibschtell Altstetten, Zürich, Riehen,.

Frick R. (2002) Die ersten 100 Jahre. In: Was kann aus Nazareth Gutes kommen? Aus der 125jährigen Geschichte der Diakonischen Gemeinschaft und Westfälischen Diakonenanstalt Nazareth/Bethel, Bethel-Beiträge 58 (eds Bauer, H., Buntrock, A., Frick, R., et al.), pp. 9-66. Bethel-Verlag, Bielefeld.

Gramlich B. (1967) Bodelschwingh, Bethel und die Barmherzigkeit. Gütersloher Verlagshaus Gerd Mohn, Gütersloh.

Hackmann M. (1999) Interviews in der historischen Pflegeforschung. Pflege 12, 28-33.

Händler-Schuster D. (2011) Institutional family systems and the role of the housemother 19451995. A hermeneutic-interpretive study of the retrospective experiences of former housemothers in homes for 'the Sick and Needy' in a diaconical institution - methodologically informed by the principles of grounded theory. Pflege 24, 271-272.

Händler-Schuster D., Schulz M. \& Behrens J. (2011) ' . . . and then I was completely taken by surprise - this was utter pioneer work' Family enterprise systems using the example of the house-mother function - methodologically informed by the principles of grounded theory. Pflegewissenschaft 7-8/11, 404-412.

Händler-Schuster D, Schulz M. \& Behrens J. (2012) 'My reward is being able to serve' Housemothers' retrospective memories of the loss of power of their position in houses 'for the sick and needy' between 1945 and 1995. Pflege. (in print)

Häusler M. (2007) Wichern und die männliche Diakonie. In: Johann Hinrich Wichern - Erbe und Auftrag (eds Herrmann, V., Gohde, J. \& Schmidt, H.), pp. 181-190. Universitätsverlag Winter GmbH, Stand und Perspektiven der Forschung. Bd. 30. Heidelberg.

Heinz W.R. \& Behrens J. (1991) Statuspassagen und soziale Risiken im Lebensverlauf; das Forschungsprogramm des Sfb 186. Bios, Zeitschrift für Biographieforschung und Oral History 4, 121-139.

Lamnek S. (2005) Qualitative Sozialforschung. Lehrbuch, Psychologie Verlag Union, München, Weinheim.

Meyer zu Bargholz M., Bensiek H., Egli U., et al. (1975) Begegnung der Geschlechter. Richtlinien für Mitarbeiter und Patienten. Sonderdruck aus dem Informationsblatt für Mitarbeiter der v. Bodelschwinghschen Anstalten. Der Ring Nr. 7-8.

Neumann R. (2010) Die westfälische Diakonenanstalt Nazareth 1914-1954. Jahrzehnte der Krise. Luther Verlag, Bielefeld.

Nussbicker R. (2009) Freistatt, Heimerziehung und die Westfälische Diakonenanstalt Nazareth. In: Endstation Freistatt Fürsorgeerziehung in den v. Bodelschwinghschen Anstalten Bethel bis in die 1970er Jahre (eds Benad, M., Schmuhl, H.W. \& Stockhecke, K.), pp. 217-224. Verlag für Regionalgeschichte, Bielefeld.

Obst H. (2002) A. H. Francke und die Franckeschen Stiftungen in Halle. Vandenhoeck \& Ruprecht, Göttingen.
Oevermann U. (1997) Theoretische Skizze einer revidierten Theorie professionalisierten Handelns. In: Pädagogische Professionalität. 2. Auflage (eds Combe, A. \& Helsper, W.), pp. 70-140. Suhrkamp Verlag, Frankfurt am Main.

Popitz H. (1992) Phänomene der Macht. 2. erweit. Aufl. Mohr Siebeck, Tübingen.

Randzio B. (2008) Von der Dienstgemeinschaft zur Teamarbeit. Die Reform der Psychiatrie in den v. Bodelschwinghschen Anstalten Bethel 19671996. In: 1968 und die Kirchen (eds Hey, B. \& Wittmütz, V.), pp. 149-161. Verlag für Regionalgeschichte, Bielefeld.

Roth F. (2010) Macht und Herrschaft bei Max Weber. Available at: http://www.florianroth.com/texte/pdfs/Max_Weber_Macht_ Herrschaft.pdf (accessed 2 September 2010).

Sattler D. (2007) Johann Hinrich Wichern: Von Christus begeistert - ein wacher Zeitgenosse. In: Johann Hinrich Wichern - Erbe und Auftrag. Stand und Perspektiven der Forschung (eds Herrmann, V., Gohde, J. \& Schmidt, H.), pp. 12-21. Band 30. Heidelberg, Universitätsverlag Winter GmbH.

Steinbrück J. (2001) Von der Fürsorge zur Leistung? Neue Personal-(entwicklungs)konzepte in der Sozialen Arbeit am Beispiel der Diakonie, Aachen, Mainz.

Strauss A. \& Corbin J. (1996) Grundlagen qualitativer Sozialforschung. Psychologie Verlags Union, Weinheim.

Tegtmeyer P. (1948) Wir werden seine Wunder sehn! Erinnerungen und Erfahrungen aus der Geschichte des Brüderhauses Nazareth von 1923-1948. Brüderrat der Diakonenanstalt Nazareth, Bielefeld.

Weber M. (1980) Wirtschaft und Gesellschaft. Grundriß der verstehenden Soziologie. Besorgt von Johannes Winkelmann, 5. Rev. Aufl., Studienausgabe. Mohr, Tübingen. 